Вісник Львівського університету. Серія філос.-політолог. студіi. 2020. Випуск 29, с. 75-83

Visnuk of the Lviv University. Series Philos.-Political Studies. Issue 29, p. 75-83

УДК 1(091):165.162:165.63

DOI https://doi.org/10.30970/PPS.2020.29.10

\title{
INTENTIONALITY AND AKRASIA IN THE CONTEXT OF CLASSICAL RATIONALITY CRITICS
}

\author{
Nataliia Kovtun \\ Zhytomyr Ivan Franko State University, \\ Historical Faculty, Department of Philosophy and Politology \\ Velyka Berdychivska str., 40, 10008, Zhytomyr, Ukraine \\ Iryna Vitiuk \\ Zhytomyr Ivan Franko State University, \\ Historical Faculty, Department of Philosophy and Politology \\ Velyka Berdychivska str., 40, 10008, Zhytomyr, Ukraine \\ Liudmyla Shkil \\ National Pedagogical Dragomanov University, \\ Faculty of Philosophy and Science, \\ Department of Culturology and Philosophical Anthropology \\ Pyrogova str., 9, 01601, Kyiv, Ukraine
}

In the article on the basis of phenomenological and hermeneutical methodology of scientific analysis, intentional acts are considered as a source of rational action. The purpose of the article is the analysis of intentional acts and weakness of will manifestations in the context of the six provisions of classical rationality criticism in John Searle's theory of social action.

Intentional acts that are realized within the process of cognition, beliefs and desires formation, in John Searle's interpretation can be both rational and irrational. The philosopher identifies three key forms of intentional gaps: in the process of developing a rational plan of activities and the formation of prior intention, in the transition from prior intention to activity, in a willful effort to carry out specific activities. If there are not enough rational rules and norms to overcome the intentional gaps, one, on the basis of free will, has to determine, which of the foundations should be used to obtain the optimal solution.

Any situation of choice is interpreted by the thinker as initially non-rational or irrational. Instead, to make a rationally motivated choice, a person has to activate his own will in order to choose the most optimal solution from all possible options. It is stated in the article that rationality is not always the result of following a certain system of rules and regulations. It can also be assimilated on an unconscious irrational level, such as while unconscious, often spontaneous, assimilation of the native language. Instead, in a situation of learning a foreign language and mastering understood grammatical and stylistic rules, a person uses rationally motivated volitional efforts.

The key conclusions of the article are realized in the position that intentional gaps are capable of producing weakness of will (akrasia). The weakness of will, according to American philosopher, arises if there are several attractive alternative activities available. It is not only a universal natural form of irrationality, but also a particular existential and social phenomenon that always accompanies human existence.

It is stated in the article that a person arbitrarily shows weakness of will. This happens when a person consciously ignores the activity, even when there are quite sufficient, rationally justified, grounds for activity manifestation. In such a sense, the promise in John Searle's interpretation is treated as one of the key means of overcoming intentional gaps, which are the basis for identifying the weakness of will in the social environment.

Key words: rationality, rationality in action, intentionality, intentional rupture, weakness of will, akrasia.

(C) N. Kovtun, I. Vitiuk, L. Shkil, 2020 
Introduction. Growth of interest in the study of the communicative rationality concept is caused by need to analyze the transformation of human role in the modern world, determine their level of reasonableness, morality and the ability to quickly adapt in a situation of increasing social transitivity and uncertainty. Humanity is increasingly convinced that the focus on technological progress and rationally motivated economic viability, predatory use of natural resources and depletion of human capital, will have a destructive impact on the future of civilization.

Analysis of the phenomenon of rationality is implemented in different concepts of rationality, which were formed on the basis of works by Aristotle, K. Aidukevych, K.-O. Apel, M. Weber, J. Habermas, H. Gadamer, M. Heidegger, G. Hegel, E. Husserl, R. Descartes, I. Kant, T. Kuhn, I. Lakatos, K. Popper, P. Feyerabend, K. Jaspers and others. Rene Descartes' understanding of rationality not only laid the modern groundbreaking concepts, but also allowed to introduce into the scientific discourse the principles of obviousness, authenticity and evidence as criteria of rationality. These principles not only attested to the autonomy of the subject of the cognition process, but also allowed to demarcate scientific and non-scientific, true and false knowledge.

In the context of the classical model, rationality is considered to be a particular constant of culture, which not only helps to explain the basic aspects of human existence in the natural and social environment, but also determines the further strategy of their activity. But in the plane of non-classical rationality both the subject and the object are regarded as mutually determined in a single system of cognition. The subject naturally loses its status of autonomy in such a case. In post-non-classical epistemology (in the terminology by V. Stepin) the search for absolute truth has been replaced by the belief in potential equality, pluralism of different approaches to the practice of constructing objects of cognition process by the subject.

In modern philosophy, there is a clear tendency to assert pluralism of types of rationality, in which rationality is reduced to the technology of peculiar paradigms of human life. In this meaning rationality is interpreted as metarationality, which contains not only the mental epistemological component. At the level of intentional acts of consciousness actualization rationality starts to correlate with the emotional and volitional spheres of the subject's activity. So the need for a detailed study of J. Searle's concept of rationality becomes of great relevance, as the starting point of it is a statement about immanent connection of the cognitive and social spheres of human activity. The work of the academic "Rationality in Action" (2001) is devoted to the analysis of the relationship between the activity of the mind and human activity in the social environment.

Interest in the study of J. Searle's rationality understanding becomes even more relevant in a situation of accelerating technological progress in the context of the fourth industrial revolution. This is reflected in scientific research works aimed at solving the problem of the relation between brain activity and consciousness in the plane of artificial intelligence development. Thus, on the one hand, Israeli scholars Gene Askenazi and Joseph Lehman, on the basis of John Searle's works analysis came to the conclusion that in the understanding of the American philosopher consciousness is interpreted as a systemic biological feature of man. Such a biologicalization of consciousness paved the way for his far-reaching assumptions about the possibility of replacement of both consciousness and human brain [1]. On the other hand, Elizabeth Hildt [3] analyzed J. Searle's work in the field of comparing the essential features of consciousness and artificial intelligence. An American researcher emphasizes that it was the author of Rationality in Action, who concluded that machines lack consciousness, reason, and sensitivity, but only stimulate thought and understanding. On this basis, Elizabeth Hyldt made a reasonable conclusion about the fundamental lack of consciousness and artificial intelligence in our current robots [3]. Another plane of John Searle's ideas actualization in contemporary philosophical discourse is the analysis of the causes of rationality disorders in some groups of people. In this regard the study of Kristina 
Lekic is of great demand as the subject of which was the study of John Searle's understanding of the intentionality principle in the sphere of autism analysis. Searle's conclusion about the impossibility of reducing collective intentionality to individual intentionality is focused on in the Bulgarian researcher's works [4]. However, despite the interest of scientists in some aspects of John Searle's research works, the problem of analyzing the correlation between intentionality and weakness of will by the American philosopher remains insufficiently investigated.

The purpose of the study is to analyze the intentionality and the weakness of the will in the context of the conceptual provisions of classical rationality critique in John Searle's work "Rationality in Action".

Discussion and some results. The principles of classical rationality are explored by John Searle through the lens of human social reality construction. The American philosopher argues that it is the existence of constructive rules in the activity that differentiates human sociality from the collective behavior of animals. If the behavior of an animal is variably restricted and regulated by instincts, then the person creatively constructs his own reality, using different types of social agreements. The effectiveness of any rule application puts the thinker in dependence on the quality of its representation at the level of collective intentionality. Collective intentionality, as a focus on the transformation of subjective and objective realms of reality, depends, according to Searle, on the linguistic practices of the subject of activity. Based on the identification of language and consciousness, he argues that language is perhaps the only universal logical phenomenon that allows a person to structure and construct reality. Beyond language not only any socially significant thought is possible, but any form of collective action.

In "Rationality in Action" to analyze the impact of rationality on the motivation of human activity, John Searle focuses on criticizing the fundamental principles of the classical paradigm of rationality. Within its limits, only a decision obtained from the choice out of several mutually exclusive foundations was declared rational. On the contrary the philosopher substantiates the position according to which the real choice of grounds for rational action is influenced by the free will, interests and desires of persons themselves. It is the intentional acts of consciousness of the subject in this sense that are considered a source of rational action. In general, criticizing the classical model of rationality, Searle makes six key points of its contradiction. The first proposition of classical rationality, the philosopher considers the idea that rational actions are caused by beliefs and desires, which are both the causes and the basis of human activity [6, p. 8]. Rationality in such an interpretation coordinates the beliefs and desires of the person for the sake of keeping them in the field of common sense. On the contrary, John Searle argues that in fact, beliefs and desires are the basis of not so much rational but irrational forms of human activity. To justify this position, he gives an example of choosing one of the candidates during the vote. The voter chooses, considering different alternatives, because he does not yet realize rationally the best of them. Actually, the choice is made only when a person realizes that the sum of his knowledge, beliefs and desires is not yet sufficient for an actual decision [6 p. 12-14]. Therefore, the choice situation is interpreted by the scholar as initially nonrational or irrational. Instead, in order to make rational choices, one has to activate one's own will in order to choose the most optimal solution of all possible options.

The second proposition of the classical model of rationality John Searle associates with the understanding of the rules as a special boundary between rational and irrational thinking and behavior. However, most people, according to the philosopher, follow many rules of rationality quite unconsciously. For example, they can speak English without knowing grammar rules or use prose without knowing that they speak prose [6, p. 8]. On this basis, the scholar makes a reasonable conclusion, that the structure of intentional states and constructive rules of linguistic acts 
initially contains the requirements of rationality [6, p. 17-21]. John Searle's reasoning make it possible to conclude that rationality is not always the result of following a certain system of rules and regulations. It can also be acquired at the unconscious irrational level. This type of mastery of rational rules is characteristic of learning the mother tongue. This type of acquiring rational rules is characteristic of learning the mother tongue. Studying a foreign language, for the purpose of mastering conscious grammatical and stylistic rules, a person uses rationally motivated volitional efforts.

In the classical model of rationality, according to the third point of John Searle's criticism, rationality is considered an attributive cognitive capacity of the person. This approach was initiated by Aristotle, who considered mind (rationality) and language essential features of human being, distinguishing them qualitatively from animals [6, p. 8-9]. Contrary to these considerations, the American philosopher does not consider rationality an attribute characteristic of human essence. In his opinion, there is no special capacity for rationality other than the capacity for language, thinking, perception and other forms of intentionality [6, p. 22]. Moreover, rationality exists only where the possibility of irrationality exists [6, p. 23-24]. In other words, rationality and irrationality appear only where there is an intentional gap, where some intentional phenomena are not enough to produce a result. In such cases, the person has to consciously decide, on the basis of free will, which of the wide range of foundations should be used to obtain the optimal solution.

Fundamental to the study of communicative rationality is the fourth position of John Searle's critique of classical rationality. According to the "classical model" of rationality, cases of weakness of will (akrasia) are considered impossible. However, if the preconditions of any process are rational and causal, then the action must necessarily take place. If, under the influence of akrasia, a person does not act in accordance with the situation, within the classical model of rationality the reasonable answer is that there were false foundations for action initially established. Contrary to this position, John Searle argues that the weakness of will was and remains a key problem in the classical model of rationality, for akrasia is considered in it to be something weird and incomprehensible [6, p. 9-10]. Contrary to the classical model of rationality, the American philosopher argues that akrasia is a universal natural form of irrationality and a natural consequence of the gap between different forms of intentionality. Akrasia occurs at the moment of the gap between the intentional states, resulting in a large number of variants open to human activity. And, no matter how rationally the subject determines the preconditions of his own activity, he is able to show weakness of will at any stage of decision making [6, p. 24-25]. In most situations of identifying different forms of social activity, the subject has a wide range of choices, often failing to give priority to one of them. Thus, the weakness of will in John Searle's interpretation is not only a universal natural form of irrationality, but also an existential and social phenomenon that will always accompany human existence.

In "Rationality in Action" John Searle makes a comparative analysis of akrasia and self-deception. On the one hand, he outlines the common characteristics of these phenomena related to their opposition to the individual's desire. However, if the essential manifestation of akrasia is a conscious, rationally motivated, opposition to the desire of the subject, then self-deception is based on a false belief, which also opposes the desire of the person. For example, a lover, in spite of the bitter reality, is deceiving himself by the fact that his beloved is faithful to him, because he desperately wants to believe in her love [9, p. 234]. On the other hand, the philosopher points to the differences between akrasia and self-deception. If a person with a weak will can leave the situation unchanged, a person who is deceiving himself cannot say to himself: yes, I know that what I believe in is absolutely false, however contrary to my knowledge, I will continue to believe it 
[6, p. 234]. In order to commit self-deception, one must suppress one's knowledge by offsetting their meaning in real life. On this basis, John Searle considers akrasia "the name of a certain type of conflict between intentional states" when the false party wins. Instead, self-deception is interpreted as special "form of conflict-avoidance by suppression of the unwelcome side" [6, p. 235]. Self-deception in this sense is interpreted as a special form of concealing an already existing conflict. And akrasia appears as the inability of the subject to make a specific decision, which may result in their inaction, mental and social apathy.

Consistent with the doctrine of John Searle's akrasia is the concept of "new opacity" (Die neue Unübersichthchkeit) in the theory of communicative rationality by Jurgen Habermas. This phenomenon of the modern information space is connected with the inability of a person to objectively analyze the excessive amount of information received, which is perceived by the subject of cognition mainly by faith. Such a social agenda prevents "the prospects of a future collective, better and less dangerous life" from emerging [2, p. 147]. Communicative rationality thus performs the function of generating universal cultural meanings, capable of being spiritual orientations for the development of man and society in the face of increasing social instability.

The communicative form of rationality is related to the fifth position of John Searle's criticism of classical model of rationality. According to it, the rationalization of activity in the realm of practical reason begins with a description of the current goals, key desires, aspirations and intentions of the subject of activity. Until there is a certain set of desires and aspirations, there is no field of activity for the mind of the subject. Thus, the thesis of the absence of reasons independent of desires of activity is, according to the academic, a key position of the classical model of rationality [6, p. 10-11]. Rational activity in this sense must be based on a clear awareness of their own desires. Contrary to these considerations, John Searle argues that there are also reasonable principles of activity independent of desires [6, p. 26, 28]. A person's ability to be aware of and use reasonable grounds for activity, independent of desires, qualitatively distinguish, according to the thinker, qualitatively distinguish the human mind from the psyche of the closest animal relatives. The validity of Searle's ideas is also confirmed by the fact that desires themselves cannot be the only basis for rationality, because they may contain irrational unconscious intentions in their structure.

John Searle derives the sixth criterion for classical rationality from the proposition that rationality is effective only when the ascending desires of the subject are mutually consistent. "If rationality is a matter of reasoning logically, there cannot be any inconsistencies or contradictions in the axioms" [6, p. 11-12]. The philosopher argues the fundamental fallacy of this provision as in real life reasoning is mainly about choosing in a situation of a particular set of preferences. In fact, the choice of a rational solution is the result of successful reasoning, not its precondition $[6, p .30]$. Therefore, such a set of preferences cannot be a precondition for a subject's desires and aspirations.

To sum up, John Searle's concept of rationality substantiates the idea of the absence of continuous causality as an attributive trait of rationality that binds beliefs, motives, and activities into a single sequence in the decision-making process. In the philosophy of reason, according to Searle, the contradictory relationship between intentionality and causality dominates. Causality is treated as an ontological phenomenon, as a relation between real events in the world. Instead, intentionality is regarded "not generally as a natural phenomenon" but as something transcendent, which is not part of the natural world [5, p. 112]. But nevertheless, the American philosopher has set himself the goal of "naturalizing intentionality" [5, p. 112].

John Searle explains the lack of clear causal link between the different stages of thinking by the presence of three key forms of intentional gaps in a single process of reasoning. In his 
interpretation, the first form of intentional rupture is realized during the overall understanding of the situation, the development of a rational plan of activities and the formation of prior intention. Alongside the prior intentions, the philosopher also identifies intentions-in-action [6, p. 60]. Preventive thinking about the situation is unlimited in time and involves a conscious choice from several ascending positions.

In the field of prior intent Searle interprets beliefs as a particular intentional state, which is "an intentional state with conditions of satisfaction" [6, p. 60]. Intensive action thus consists of two components: "an intention-in-action and a bodily movement". The philosopher substantiates the position that the actions themselves do not provide the conditions for their implementation. Only intentions to action have the conditions for implementation, not the activity itself. Thus, John Searle concludes, action will only be successful after the "intention-to-action is satisfied" $[6$, p. 60]. Otherwise, the action does not take place and the person gets into a state of inactivity or social apathy. The theorist correlates the second form of intentional break with the transition from prior intention to activity itself [6, p. 231]. It is precisely the gap between intention and action, according to Searle, that many of the cases of weakness of will are explained by [6, p. 232]. The reason for this is the inevitable collision of desires or other factors of motivation for a predetermined activity. And therefore, there is always the possibility that a person simply does not want to do what he intended.

The third form of intentional gap is realized in the temporal structure of activity and in the willful effort necessary to finish the case. This type of intentional gap helps to explain the ratio of activity to time, for the same person, according to John Searle, should be responsible for his actions in the past and plan his own activities in the future [6, p. 92]. Thus, it is the activity of a person in the context of intentional gap that is the basis for the acquisition "the locus of responsibility" [6, p. 89].

According to the American philosopher, any intentional action is possible only in the presence of a "conscious agent who acts", when there is "an animal agent". He can only be a conscious living being capable of initiating and operating on the basis of free will [6, p. 83]. In this sense, the direct implementation of any form of activity is impossible without the freedom of will, which is a key factor in leveling intentional gaps.

There is another important factor of closing intentional gaps that John Searle identifies in addition to free will - language. The ascending condition for reconciling the free will of the person and the institutional reality of the society, the philosopher calls a special form of speech act - a promise. It allows you to impose your will, depending on its future fulfillment of certain conditions. In fact, "every language act has an element of promise". Although philosophers have for a long time treated promises as a form of assertions, it would be more accurate to say that assertions are a kind of promise [6, p. 181].

While revealing the role of promises in social life, John Searle said that in order to "organize and coordinate our behavior, we need to create a class of entities that will have the same logical structure as desires, but will be desire-independent... The only way that such entities can be binding on rational selves is precisely if the rational selves freely create them as binding on themselves" [6, p. 206]. Promise as a special language act in the thinker's interpretation includes a self-referential component that is imposed on the conditions of fulfillment. A person does something only because he has promised to do so [6, p. 213]. In other words, a person is not only able to form an independent of desire basis for the activity; he can be fully motivated for activities in accordance with it.

In general, in the context of the intentional gap analysis, John Searle tends to phenomenologically acknowledge the unity of the thinking, volitional and emotional components of con- 
sciousness. Exploring the formal structure of intentionality, the thinker concludes that "cognition and volition are mirror images of each other". However, there are significant differences between them, because willpower may contain a gap and knowledge does not contain it [6, p. 70]. However, this position of Searle can only be partially agreed, since there are cognitive acts that contain intentional gaps. Thus, in the structure of the intuitive act of cognition instead of the established three stages (the foundations of cognition, the cognitive act itself (such as the process of solving a mathematical problem), obtaining the results of cognition) only two stages are clearly observed the foundations of cognition (such as problem statement) and the result obtained (problem solving). In fact, instead of the immediate stage of solving a problem there is an intentional gap in an intuitive act of knowing.

Conclusions. Contrary to the classical understanding of rationality, John Searle considers rationality not a result of the obligatory adherence to a particular system of rules and regulations. Rationality in his comprehension can also be acquired at the unconscious irrational level, such as in the process of mastering the mother tongue. In a broad sense the academic considers rationality a person's ability to understand and use reasonable independent of desires grounds for activity. This qualitatively distinguishes human mind from the psyche of their closest animal relatives. Rationality in such an interpretation is an integral part of the capacity for speech, thinking, perception and other forms of intentionality. Apart from rationality in the functioning of the consciousness, according to John Searle, beliefs, promises, intentions and desires play an important role as special intentional states.

Rationality and irrationality are manifested only where there is an intentional gap, where some intentional phenomena are not enough to get a result. In such a situation, a person on the basis of free will has to decide which of the wide range of foundations should be used to find the best solution. John Searle identifies three key forms of intentional gaps. The first form of intentional gap is realized in the process of developing a rational plan of activities and forming a prior intention. The second form of intentional gap correlates with the transition from prior intention to the activity itself. The third form of intentional gap is realized in the willful effort necessary to finish the case.

Intentional gaps, according to John Searle, are directly related to the phenomenon of weakness of will, akrasia. Weakness of will arises in the subject's mind as a result of several attractive alternative activities available. In many cases, a person is arbitrarily able to ignore activity even when there are sufficient, rationally justified, grounds for activity. Promise in the interpretation of the thinker is a special way of overcoming intentional gaps. It contains ethical grounds for the interaction of free actors, related by institutional responsibilities. In the plane of linguistic practice by means of promise one learns to exercise free will and take responsibility in the social environment. The direct consequence of akrasia is a person's social inactivity, their mental and social apathy. Weakness of will is not only a universal natural form of irrationality, but also a particular existential and social phenomenon that will always accompany human existence.

\section{References}

1. Askenasy J. \& Lehmann J. Consciouness, brain, neuroplasticity. Frontiers in Psychology, 10 July. 2013. DOI: 10.3389/fpsyg.2013.00412. URL: https://www.frontiersin.org/articles/ 10.3389/fpsyg.2013.00412/full.

2. Habermas J. Die neue Unübersichthchkeit. Frankfurt am Main : Suhrkamp Verlag. 1985.

3. Hildt E. Artificial Intelligence: Does Consciousness Matter? Frontiers in Psychology, 02 July. 2019. DOI: 10.3389/fpsyg.2019.01535. URL: https://www.frontiersin.org/articles/10.3389/ fpsyg.2019.01535/full. 
4. Lekic K. Collective intentionality and autism: Against the exclusion of the "social misfits". Filosofija I drustvo, 2019. No. 30(1), pp. 135-148. DOI: 10.2298/FID1901135. URL: https://www.researchgate.net/publication/331662287_Collective_intentionality_and_ autism Against the exclusion of the social misfits.

5. Searle J.R. Intentionality: An Essay in the Philosophy of Mind. Cambridge : Cambridge University Press. 1983.

6. Searle J.R. Rationality in action. Cambridge : MIT Press. 2001.

\title{
ІНТЕНЦІОНАЛЬНІСТЬ ТА АКРАЗІЯ У КОНТЕКСТІ КРИТИКИ КЛАСИЧНОЇ РАЦІОНАЛЬНОСТІ
}

\author{
Наталія Ковтун \\ Житомирський державний університет імені Івана Франка, \\ історичний факультет, кафедра філософії та політології \\ вул. Велика Бердичівська, 40, 10008, м. Житомир, Украӥна \\ Ірина Вітюк \\ Житомирський держсавний університет імені Івана Франка, \\ історичний факультет, кафедра філософії та політології \\ вул. Велика Бердичівська, 40, 10008, м. Житомир, Україна \\ Людмила Шкіль \\ Національний педагогічний університет імені М. П. Драгоманова, \\ факультет філософії та суспільствознавства, \\ кафедра культурології та філософської антропології \\ вул. Пирогова, 9, 01601, м. Київ, Україна
}

У статті на основі феноменологічної і герменевтичної методології наукового аналізу розглядаються інтенціальні акти як джерело раціональної дії. Метою статті є аналіз інтенціальних актів та виявів слабкості волі у контексті шести положень критики класичної раціональності у теорії соціальної дії Джона Серля.

Інтенціальні акти, які реалізуються у процесі пізнання, формування переконань, прагнень i бажань, в інтерпретації Джона Серля можуть бути як раціональними, так і ірраціональними. Філософ виділяє три ключові форми інтенціальних розривів: у процесі вироблення раціонального плану діяльності і формування превентивного наміру, у переході від превентивного наміру до діяльності, у вольовому зусиллі щодо здійснення конкретної діяльності. У разі, якщо для подолання інтенціальних розривів не досить раціональних правил і норм, людина має на основі свободи волі визначити, які із засновків слід використати для отримання оптимального рішення.

Будь-яка ситуація вибору тлумачиться мислителем як початково нераціональна або ірраціональна. Натомість для здійснення раціонально вмотивованого вибору людина має активізувати власну волю $з$ метою обрання найбільш оптимального рішення з усіх можливих варіантів. У статті 3'ясовано, що раціональність не завжди $є$ результатом слідування певній системі правил і норм. Вона може засвоюватись і на несвідомому ірраціональному рівні, як-от під час несвідомого, часто стихійного, засвоєння рідної мови. Натомість у ситуації вивчення чужої мови і засвоєння усвідомлених граматичних і стилістичних правил людина послуговується раціонально вмотивованими вольовими зусиллями.

Ключові висновки статті реалізуються у положенні, що інтенціальні розриви здатні продукувати слабкість волі (акразії). Слабкість волі у розумінні американського філософа виникає в ситуації наявності декількох привабливих альтернативних варіантів діяльності. Вона $є$ не тільки 
Вісник Львівського університету. Серія філос.-політолог. студії. 2020. Випуск 29

всезагальною природною формою ірраціональності, а й особливим екзистенційним і соціальним явищем, яке завжди супроводжує буття людини.

У статті встановлено, що здебільшого людина самовільно проявляє слабкість волі. Це відбувається, коли вона свідомо ігнорує діяльність навіть тоді, коли є цілком достатні, раціонально обгрунтовані підстави для проявів активності. У такому розумінні обіцянка в інтерпретації Джона Серля розглядається як один 3 ключових засобів подолання інтенціальних розривів, які $є$ основою виявлення слабкості волі у соціальному середовищі. Вона містить у собі етичні підстави взаємодії вільних суб'єктів активності, пов'язаних різними типами соціальних обов'язків.

Ключові слова: раціональність, раціональність у дії, інтенціональність, інтенціональний розрив, слабкість волі, акразія. 